\title{
PRICE SENSITIVITY VERSUS PERCEIVED QUALITY: MODERATING EFFECTS OF RETAILER POSITIONING ON PRIVATE LABEL CONSUMPTION
}

\author{
Óscar GONZÁLEZ-BENITO ${ }^{1}$, Mercedes MARTOS-PARTAL ${ }^{2}$ \\ Departamento Administración y Economía de la Empresa, Universidad de Salamanca, \\ Campus Miguel de Unamuno, 37007 Salamanca, Spain \\ E-mails: ${ }^{1}$ oscargb@usal.es; ${ }^{2}$ mmartos@usal.es (corresponding author)
}

Received 22 December 2011; accepted 16 October 2012

\begin{abstract}
Private labels are growing fast in Europe and USA, especially in the context of nondurable consumer goods. Moreover, the traditional association of private labels solely with a price focus, to the detriment of quality, appears to be diminishing. This research aims to clarify the effect of price sensitivity toward and quality perceptions of private labels on private label consumption. It analyzes the role of a retailer's price positioning as a moderator of the importance of these effects as determinants of private label purchases. With household panel data and survey information, this study investigates private labels' share of wallet as the dependent variable; thus the logit-type model is adapted to a resource allocation context. Five sequential models specify and test the four hypotheses. In support of the hypotheses, price sensitivity and quality perceptions relate positively to private label consumption. For the moderating effect of retailer's price positioning, a negative moderating effect arises for price sensitivity, whereas a positive moderating effect appears for quality perceptions of private labels. The findings indicate that retailers' efforts to convert private labels into tools to support positioning strategies are effective.
\end{abstract}

Keywords: private labels, price sensitivity, perceived quality, retailer positioning, share of wallet, Spain.

JEL Classification: M3.

\section{Introduction}

The recent growth of private labels is a key characteristic of the retail industry (Szymanowski, Gijsbrechts 2012), together with increasing heterogeneity in the offers provided by private labels. Whereas initially, private labels were solely positioned as cheaper alternatives, with price as the main reason for purchase (Burt, 2000; Cunningham et al. 1982; Harris, Strang 1985; Kumar, Steenkamp 2007; Yelkur 2000), today they encompass broad, well-balanced quality and price offerings (Dunne, Narasimhan 1999; Geyskens et al. 2010; Quelch, Harding 1996; Rubio, Yagüe 2009; Soberman, Parker 2006). Thus private label tiers suggest increasing levels of quality, such as generic, standard and premium (Geyskens et al. 2010; Kumar, Steenkamp 2007). 
Consumers no longer buy private labels only for lower prices; they also appreciate their attributes and characteristics in comparison with those of national brands. That is, private label purchases can initiate favourable attitudes toward private labels (Baltas 1997; Erdem et al. 2004; Hansen, Singh 2008; Hansen et al. 2006; Martos-Partal, GonzálezBenito 2009; PLMA 2010), and many provoke quality-level perceptions comparable to those of national brands, just at better prices. Some retailers even promote private labels as a form of smart shopping (Burton et al. 1998; Garretson et al. 2002; Manzur et al. 2011).

A commitment to quality private labels often relates closely to the retailer's positioning. Price-oriented retailers tend to sell private labels that rely more on price perceptions to prompt purchases (Dhar, Hoch 1997; Kumar, Steenkamp 2007). In contrast, more quality-oriented retailers offer private labels that are coherent with their positioning (Dunne, Narasimhan 1999; Kumar, Steenkamp 2007). When retailers own a private label portfolio, they generally align their flagship label with their primary positioning. Thus private labels reflect retailers' positioning, and retailers simultaneously use private labels to reaffirm that position. Accordingly, a retailer's positioning should affect the equilibrium between price sensitivity and perceived quality as determinants of private label consumption. When a retailer adopts a more quality-oriented position, it also adopts that approach to its private label portfolio, so perceived quality should be more important than price sensitivity in determining the purchase of these private labels.

With this article, we provide empirical evidence of this influence. First, we analyse and compare price sensitivity and perceived quality as determinants of customer purchases of private labels. Second, we study the role of a retailer's price positioning as a potential moderator of their importance as determinants of purchase. Using a sample of households that represent the Spanish population, we gather information about each household's motivations, attitudes and purchasing patterns, all with regard to food, household and personal care products, bought from the main retailer chains that operate in the Spanish grocery retailing industry.

This study therefore extends previous knowledge in two ways. First, previous research has related attitudes toward and the purchase of private labels to customer's price sensitivity (Ailawadi et al. 2001, 2008; Batra, Sinha 2000; Burton et al. 1998; Baltas, Argouslidis 2007; Sinha, Batra 1999) or to perceptions of the quality of private labels (Hoch, Banerji 1993; Richardson et al. 1994, 1996). Yet no studies have considered and compared both determinants together, though the evolution of private labels along a price-quality continuum implies the need to do so. Second, whereas researchers have studied the effect of retailers' price strategies (Dhar, Hoch 1997), no one has assessed a retailer's price positioning as a moderator of factors related to private label consumption - namely, price sensitivity and perceived quality. Trends of alignment between retailers' positioning and their private label strategy suggest the need to study the moderating role of retailer price positioning though. Moreover, private labels continue to evolve (Burt 2000; Kumar, Steenkamp 2007), and previous evidence could be outdated. Therefore, we consider a revision and update of previous evidence relevant. 
In the next section, we present our conceptual framework and review previous research to offer some theoretical support for our proposed hypotheses. After we describe the methodology for our empirical analysis, we present and discuss the findings. Finally, we outline our main conclusions and some implications.

\section{Conceptual framework: proposed hypotheses}

\subsection{Price motivation for private label consumption}

Traditionally, private label purchases related to lower prices. The first private labels were referred to as generics; their sellers emphasized basic usage and were positioned as the least expensive alternative, because they engaged in limited promotional activities, used simpler packaging, and included economical ingredients (Burt 2000; Cunningham et al. 1982; Harris, Strang 1985; Kumar, Steenkamp 2007; Yelkur 2000). However, in recent years, private labels have evolved, increased their quality, and thus jumped in price (Nielsen 2011; Steenkamp et al. 2010), though they still provide an appealing price-quality option. Modern private labels offer both sufficient quality and better prices than national brands (Apelbaum et al. 2003; Kumar, Steenkamp 2007; Mendéz et al. 2008; Sethuraman, Cole 1999; Soberman, Parker 2006).

The recent economic downturn has strengthened the association between private label purchases and price-oriented consumers, as price search dominates recent buying processes (KantarWorldpanel 2011). Consumers today tend to pay more attention to the objective value of products, prioritizing price over other characteristics, which has encouraged private label growth. As behavioural habits often persist, this trend appears likely to continue, even as economies clamber out of their recessions (Dekimpe et al. 2011; Lamey et al. 2007, 2012; Nielsen 2011).

Furthermore, previous academic research consistently finds a relationship between private label purchases and price sensitivity (Baltas, Argouslidis 2007; Cunningham et al. 1982; Dick et al. 1995; Fan et al. 2012; Hansen et al. 2006; Martos-Partal, GonzálezBenito 2009; Sinha, Batra 1999). Price remains an important determinant of private label choice (Ailawadi et al. 2001; Baltas 1997, 2003; Burton et al. 1998; Manzur et al. 2011; Mendéz et al. 2008; Sethuraman 2006), and product categories that induce higher price sensitivity exhibit greater private label penetration (Batra, Sinha 2000; Hoch 1996). Therefore, we propose:

H1: Consumer price sensitivity relates positively to privatelabel consumption.

\subsection{Perceived quality motivation for private label consumption}

The search for quality is a key motivation for brand choice, and some studies suggest that private label purchases relate negatively to quality or service consciousness (Ailawadi et al. 2001; Martos-Partal, González-Benito 2009). If consumers' quality consciousness relates negatively to private label purchases, then private labels must be perceived as inferior in quality.

Many private labels work to overcome this inferior quality perception. Despite their overall appealing price-quality ratio compared with national brands, the competitive 
positioning of individual private labels differs, depending on their stress on quality versus price, or the quality standard they adopt. In recent years, diversity in private label positioning has even increased, with a clear shift from price to quality propositions. Some distributors offer product lines comparable in quality or even better than those of national brands (Dunne, Narasimhan 1999; Geyskens et al. 2010; Nielsen 2011; Quelch, Harding 1996; Soberman, Parker 2006).

Evidence of the quality evolution in private labels includes both objective factors related to the products and subjective elements centred on consumer perceptions (Mendéz et al. 2008; Soberman, Parker 2006). On the objective side, Apelbaum et al. (2003) in the United States and Mendéz et al. (2008) in Spain find that the objective quality of private labels is comparable to that of national brands. Davies and Brito (2004), De Wulf et al. (2005), and Fornerino and d'Hauteville (2010) confirm these results using blind tests: When consumers do not know the brand, they do not differ in their preferences. The PLMA (2011) also emphasizes the lack of objective quality differences between national and store brands, such that in blind tests, 23 of 29 store brand categories earned evaluations equal or superior to those of national brands.

On the subjective side, some studies indicate improvements in private label perceptions. Nielsen (2011) study reveals that half of U.S. and European consumers consider private labels a good alternative to name brands, and one-third consider them just as good as name brands. The PLMA (2010) also confirms that buyers believe store brands work as well as national brands. These trends have resulted from retailers' communication efforts to establish quality images, credibility and reputation for their private labels (Consumer Reports 2009; Kumar, Steenkamp 2007). Other factors contributing to these improved perceptions are the recognition that the suppliers of private labels often are national brand manufacturers and consumers' beliefs that private labels simply imitate national brands (Consumer Reports 2009; Kumar et al. 2010; Olson 2012; Steenkamp et al. 2010).

Because quality perceptions of private labels are improving, we anticipate that not all private label consumption is linked to price convenience; it also may be explained by quality determinations, in terms of functionality, quality or performance. Consequently, we expect that quality perceptions of private labels help explain private label consumption. We find some support in prior research, which indicates a relationship between private label purchases and perceived quality. Sethuraman's (2006) review concludes that perceived quality has a positive effect on private label proneness and purchase; other evidence indicates that quality may be of equal or greater importance than price (Bao et al. 2010; Hoch, Banerji 1993; Fan et al. 2012). That is, private label consumers want lower prices without any loss of quality. Richardson et al. (1996) point out that perceived quality has more influence on private label proneness than perceived value. Moreover, attitude toward private labels relates positively to private label purchase (Baltas 1997; Burton et al. 1998; Garretson et al. 2002; Hansen, Singh 2008; Hansen et al. 2006; Martos-Partal, González-Benito 2009). Thus, we propose that:

H2: Quality perceptions of private labels relate positively to private label consumption. 


\subsection{Moderating role of retailer positioning}

Retailers adjust their supply to satisfy customers' demand. Customers' needs include price, assortments and services, which determine their choices for a point of sale (e.g., big or small stores, more or fewer private labels, everyday low or high-low price policy; Dekimpe et al. 2011). The dimensions that retailers use to differentiate their offers and appeal to target customers constitute their competitive positioning. However, price is perhaps the primary dimension (Ailawadi, Keller 2004). Consumers generally consider a store's price image when choosing among stores and store formats (Pan, Zinkhan 2006; Rhee, Bell 2002; Zielke 2010). Even if they have little knowledge of the individual prices of products, they recognize certain price distinctions for different stores (Alba et al. 1994; Dickson, Sawyer 1990).

Brands also can help establish a retailer's positioning (Ailawadi, Keller 2004). Private labels influence store images and allow for differentiation across stores (Semeijn et al. 2004). In addition, private label strategies tend to be coherent with a retailer's positioning, in particular its price-quality position (Luijten, Reijnders 2009); for example, a private label strategy focused on quality would not be credible at a price-oriented store. Dhar and Hoch (1997) find that stores that adopt an everyday low price (EDLP) positioning tend to sell private labels that rely more on price. However, for a retailer more focused on quality, the variety of private label positions can increase being common that the flagship private label aligns closely with the retailer's position. For example, the multinational chain Carrefour has a three-tier privatelabel portfolio in food categories; Carrefour Discount, with a price positioning; Carrefour, a well-balanced alternative in terms of quality and price; and Carrefour Selection, the high-quality label that improves the retailer's image and its differentiation from others. Its greatest effort is devoted to the Carrefour label, which represents $90 \%$ of its private label assortment (Carrefour 2011).

Thus the evolution of quality perceptions and the trend to align private labels with the retailer's positioning should have consequences for customers' motivations to buy private labels. We expect that at price-oriented stores, customers' motivations to buy private labels relate more to low prices than to quality perceptions. In contrast, at quality-oriented stores, private labels focus more on quality, so the importance of perceived quality may be higher than price for determining private label consumption. Thus:

H3: A retailer's positioning moderates the relationship between price sensitivity and private label consumption, so that higher retail prices diminish the relationship between price sensitivity and private label consumption.

H4: A retailer's positioning moderates the relationship between quality perceptions and private label consumption, so that higher retail prices strengthen the relationship between quality perceptions and private label consumption. 


\section{Study scenario and data}

According to Private Label Manufacturers Association (PLMA 2011) private label keeps gaining market share across Europe. Today, private label accounts for at least $40 \%$ of all products sold in Switzerland, Spain, the United Kingdom, Portugal and Germany. Also, in emerging retail markets such as Poland, Czech Republic, Slovakia and Turkey private brands are winning market share.

In this study we focus on the Spanish context. Spain is a suitable scenario for our study because it constitutes one of the leading European countries in terms of private labels development. Specifically, we focus on 12 retail chains that operate in the Spanish retail industry: Mercadona, Carrefour, Eroski, Alcampo, Dia, Hipercor, Caprabo, Lidl, Dinosol, Consum, Ahorramas and Miguel Alimentación. The 2008 Annual Food Distribution Report (Alimarket 2008) ranks these chains as the top 12 positions (in order) in terms of sales value in the Spanish market. Among these retailers, we distinguish between discounters that use EDLP and those that adopt other strategies. Dia and Lidl both are discounters, but whereas Lidl employs a hard discount strategy, Dia follows a soft discount strategy. According to this traditional classification, hard discounters have a more limited product range, are more focused on dry goods, and have a narrower national brand assortment than do soft discounters (IGD Research 2007). The Mercadona supermarket chain uses an everyday low pricing (EDLP) strategy, and the other 9 retailers follow a high/low pricing (Hi-Lo) strategy.

Data provided by the TNS household panel (now KantarWorldpanel), which effectively represents the Spanish population, indicate annual expenditures (second half of 2007 to first half of 2008) for three broad product categories: food, household and personal care products. The data also indicate each household's expenditures with the 12 top retailers and the aggregated expenditures for other retailers.

These data enable us to compute our dependent variable, which is the share of wallet devoted to private labels by each household at a preferred retail chain. To determine the preferred retail chain, we analyse expenditure distributions across retail chains and define the preferred chain as the retailer that receives the greatest expenditure from each household (East et al. 2000). Because we only have information for the top 12 retailers, we filter the initial sample and consider only those households for which aggregated expenditures to these 12 retailers were greater than $50 \%$, such that expenditures with other retail chains must be less than $50 \%$. Thus we avoid a sample that has been biased by the effects of households whose expenditures are not concentrated on the top retailers. Also, household socio-demographic information is available in the household panel; we obtain information about each household's social class.

KantarWorldpanel also conducted an "Opinions and attitudes survey" among the same panellists in July 2008. Of the more than 160 questions, we only consider those related to price sensitivity or quality perceptions of private labels. For the empirical analyses, we combine both data sources and use the households that provided full information in both sources. The final sample thus includes 775 households. Average private label share at the preferred retail chain was 0.30 . 
To measure price sensitivity and quality perceptions, we use items related to each construct that appeared in the questionnaire. These items relied on a five-point Likert-type scale $(1=$ strongly disagree, $5=$ strongly agree $)$. As we describe in Table 1 , we use three items to measure price sensitivity and two for quality perception, and we take the mean. Table 1 details the descriptive analyses of both measures. We also summarize the results from the exploratory factor analysis for both scales in Table 1.

Table 1. Item descriptions and exploratory factor analysis

\begin{tabular}{|c|c|c|c|c|c|c|}
\hline Factors & Item & M & SD & Factor score & $\begin{array}{l}\text { Variance } \\
\text { extracted }\end{array}$ & $\begin{array}{l}\text { Internal } \\
\text { consistency }\end{array}$ \\
\hline \multirow[t]{4}{*}{$\begin{array}{l}\text { Price } \\
\text { sensitivity }\end{array}$} & $\begin{array}{l}\text { I always compare prices } \\
\text { among different brands } \\
\text { before choosing one. }\end{array}$ & 3.73 & 0.78 & 0.85 & 68.67 & $0.77^{1}$ \\
\hline & $\begin{array}{l}\text { I compare prices to take } \\
\text { advantage of special offers. }\end{array}$ & 3.87 & 0.74 & 0.79 & & \\
\hline & I look for bargains. & 3.58 & 0.79 & 0.83 & & \\
\hline & Mean across items & 3.73 & 0.64 & & & \\
\hline \multirow[t]{3}{*}{$\begin{array}{l}\text { Quality } \\
\text { perceptions }\end{array}$} & $\begin{array}{l}\text { Private labels are made by } \\
\text { the same manufacturers as } \\
\text { national brands. }\end{array}$ & 3.97 & 0.69 & 0.86 & 74.90 & $0.49^{2}$ \\
\hline & $\begin{array}{l}\text { Private labels have the same } \\
\text { quality as national brands. }\end{array}$ & 3.71 & 0.75 & 0.86 & & \\
\hline & Mean across items & 3.84 & 0.62 & & & \\
\hline
\end{tabular}

Notes: ${ }^{1}$ Cronbach's alpha; ${ }^{2}$ Correlation.

We also considered the households' social class as a control variable. This information comes from TNS household panel, that distinguishes four groups: low (social class 1), medium-low (social class 2), medium (social class 3) and high-medium to high (social class 4). These classes are assigned using detailed data about households' properties, equipment and habits, although we did not have access to disaggregated data in this regard. $12 \%$ of the analyzed households is in social class $1,24 \%$ in social class $2,40 \%$ in social class 3 and $22 \%$ in social class 4 .

To quantify the price positioning of the retailers, we use data about their price levels, published by the Consumers and Users Organization (OCU 2008), which conducts an annual price comparison of retailers in the Spanish market. In 2008, the OCU study gathered data about 800 geographically dispersed stores of 67 retail chains, compared the prices for a basket of products that a normal Spanish family likely would purchase, and computed a price index for cheaper brands. These data led to a price index for each store and, through aggregation, for each retail chain. A value of 100 represents the cheapest store, so a store with a 118 index charges $18 \%$ more than does the cheapest store. We report price indexes for the 12 analyzed retailers in Table 2.

Table 3 also summarizes the sample distribution across preferred retail chains. Mercadona is the most preferred retail chain with the greatest percentage of customers (.31), followed by Carrefour (.20), Eroski (.16) and Dia (.13). 
Ó. González-Benito, M. Martos-Partal. Price sensitivity versus perceived quality: moderating effects ...

Table 2. Price level and customer distributions across retail chains

\begin{tabular}{lccc}
\hline \multicolumn{1}{c}{ Retail chains } & $\begin{array}{c}\text { Price } \\
\text { level }\end{array}$ & $\begin{array}{c}\text { Customers' distribution across } \\
\text { preferred retail chain }\end{array}$ & $\begin{array}{c}\text { Customers' percentage } \\
\text { across preferred retail chain }\end{array}$ \\
\hline Mercadona & 118 & 246 & 0.31 \\
\hline Carrefour & 104 & 157 & 0.20 \\
\hline Eroski & 106 & 125 & 0.16 \\
\hline Alcampo & 106 & 61 & 0.07 \\
\hline Dia & 105 & 103 & 0.13 \\
\hline Hipercor & 147 & 3 & 0.003 \\
\hline Caprabo & 113 & 21 & 0.02 \\
\hline Lidl & 102 & 13 & 0.01 \\
\hline Dinosol & 125 & 2 & 0.002 \\
\hline Consum & 117 & 15 & 0.01 \\
\hline Ahorramas & 119 & 27 & 0.03 \\
\hline Miguel alimentación & 135 & 2 & 0.002 \\
\hline
\end{tabular}

\section{Analysis and findings}

Our dependent variable is the share of wallet devoted to private labels in the preferred retail chain. The control variables include the preferred retail chain for each household and social class. Finally, we specify as independent variables the respondents' price sensitivity, quality perceptions, and their interactions with the assigned prices of the preferred retail chain. Because our dependent variable relies on a share measure, we use a logit-type model adapted to the resource allocation context (Ailawadi et al. 2008). Therefore, we propose:

$$
\pi_{i}=\frac{e^{\alpha+\sum_{j} \delta j D_{i j}+\lambda Z_{i}+\beta P S_{i}+\chi Q P P L_{i}+\varphi P S_{i} * P M R_{i}+\theta Q P P L_{i} * P M R_{i}}}{1+e^{\alpha+\sum_{j} \delta j D_{i j}+\lambda Z_{i}+\beta P S_{i}+\chi Q P P L_{i}+\varphi P S_{i} * P M R_{i}+\theta Q P P L_{i} * P M R_{i}}},
$$

where $\pi_{i}$ indicates the share of wallet to private labels spent by household $i$ at the preferred retailer chain. $\alpha$ denotes a parameter to be estimated, which quantifies the degree of loyalty to private labels. $D_{i j}$ is a dummy variable that assumes the value of 1 when household $i$ prefers retailer $j$. $\delta j$ denotes a parameter to be estimated that quantifies the differential effect, beyond private label loyalty, when the preferred retail chain is $j$ (one retail chain serves as a reference with a null parameter). $Z_{i}$ is a vector of social class variables; $\lambda$ is a vector of parameters for estimation that captures the effect of social class (one variable serves as the reference with a null parameter). $P S_{i}$ is the price sensitivity of household $i, Q P P L_{i}$ is the quality perception of private labels. $P S^{*} P M R_{i}$ refers to the interaction between price sensitivity and the price level of the 
preferred retail chain. $Q P P L^{*} P M R_{i}$ refers to the interaction between quality perceptions of private labels and the price level of the preferred retail chain; and $\beta, \chi, \Phi$ and $\theta$ are parameters to estimate and correspond respectively to the previous variables. The direct effect of $P M R_{i}$ is not considered, because it is redundant. The price level depends on the preferred retail chain.

In Table 3, we report the estimation results. We estimate five sequential models: a first model with only social class and retail constants as explanatory variables, second and third models that separately add price sensitivity and quality perceptions, a fourth model that analyzes the joint effect of both variables and finally a model that includes the interaction effect of the price level of the preferred retailer with price sensitivity and quality perceptions. For estimation, we used the command glm (generalized linear model) from STATA software that was developed to estimate binary logit-type models in which the dependent variable is a proportion instead of a dummy variable (McDowell, Cox 2004). In order to simplify the interpretation of our estimation results, our key explanatory variables (price sensitivity, quality perceptions, and price level) were mean-centered.

The parameters for the effect of the preferred retail chain (model 1) indicate significant differences in private label consumption across retail chains. The importance of private labels is greater for the discounter chains, Dia and Lidl. In addition, Mercadona, Eroski and Carrefour have made notable efforts to develop their own labels (Alimarket 2007; Eleconomista 2010; KantarWorldpanel 2010). Concerning the social class control variables, we find that social class 2 (medium-low) and social class 4 (high) are less prone to private label consumption.

With respect to the direct effects of price sensitivity and quality perceptions (models 2 and 3), we find that both relate positively to private label consumption. They also remain positively significant when we include them both simultaneously (model 4). That is, each variable has its own effect, regardless of their relationship with the other, in support of $\mathrm{H} 1$ and $\mathrm{H} 2$.

Therefore, yet private label consumers tend to have higher price sensitivity, and price remains a key claim of private labels. Also private label purchases can be explained by higher quality perceptions, so retailers' efforts to improve private label positioning imply a sales increase.

Finally, for the retailer's price positioning, we find a negative moderating effect on price sensitivity and a positive moderating effect on quality perceptions of private labels (model 5). These results confirm H3 and H4. As the price level of the retail chain increases, the quality perception of private labels gains importance, rather than price sensitivity, as a means to explain private label consumption. These finding are consistent with the trend in which private labels appear coherent with the retailer's positioning. More quality-oriented retailers, with higher price levels, tend to manage higher-quality private labels. They still promise a good price-quality ratio compared with national brands, but their quality level increases, attracting consumers who are less worried by price and more concerned about quality, attributes and benefits. 
Table 3. Estimation results

\begin{tabular}{|c|c|c|c|c|c|}
\hline & Model 1 & Model 2 & Model 3 & Model 4 & Model 5 \\
\hline Constant & $-2.12 * * *$ & $-1.80 * * *$ & $-1.77 * * *$ & $-1.71 * * *$ & $-1.76^{* * *}$ \\
\hline Mercadona & $1.34 * * *$ & $1.23 * * *$ & $1.18 * * *$ & $1.13 * * *$ & $1.17 * * *$ \\
\hline Carrefour & $0.82 * * *$ & $0.68 * * *$ & $0.70 * * *$ & $0.62 * * *$ & $0.66^{* * *}$ \\
\hline Eroski & $1.23 * * *$ & $1.08 * * *$ & $1.08 * * *$ & $1.01 * * *$ & $1.06 * * *$ \\
\hline Alcampo & 0.08 & -0.05 & -0.04 & -0.11 & -0.07 \\
\hline Dia & $1.97 * * *$ & $1.81 * * *$ & $1.82 * * *$ & $1.73 * * *$ & $1.78 * * *$ \\
\hline Hipercor & $0.95^{*}$ & $0.89 *$ & $0.86^{*}$ & $0.84 *$ & 0.80 \\
\hline Caprabo & 0.08 & -0.03 & -0.08 & -0.13 & -0.07 \\
\hline Lidl & $2.94 * * *$ & $2.77 * * *$ & $2.81 * * *$ & $2.70 * * *$ & $2.73 * * *$ \\
\hline Dinosol & -0.18 & -0.28 & -0.28 & -0.33 & -0.27 \\
\hline Consum & $0.32 * *$ & 0.20 & 0.16 & 0.11 & 0.16 \\
\hline Ahorramas & 0.31 & 0.20 & 0.15 & 0.10 & 0.14 \\
\hline Miguel alimentación & -- & -- & -- & -- & -- \\
\hline Social Class 2 (medium-low) & $-0.16^{* *}$ & $-0.17 * *$ & $-0.19 * *$ & $-0.18^{* *}$ & $-0.20 * *$ \\
\hline Social Class 3 (medium) & 0.002 & -0.01 & -0.02 & -0.03 & -0.03 \\
\hline Social Class 4 (high) & $-0.14^{*}$ & $-0.16^{* *}$ & $-0.18 * *$ & $-0.18 * *$ & $-0.19 * *$ \\
\hline Price sensitivity & & $0.18 * * *$ & & $0.15 * * *$ & $0.15^{* * *}$ \\
\hline Quality perceptions & & & $0.16^{* * *}$ & $0.11 * * *$ & $0.12 * * *$ \\
\hline $\begin{array}{l}\text { Price sensitivity } \times \text { price level } \\
\text { of preferred retail chain }\end{array}$ & & & & & $-0.01 * * *$ \\
\hline $\begin{array}{l}\text { Quality perceptions } \times \text { price } \\
\text { level of preferred retail chain }\end{array}$ & & & & & $0.01 * *$ \\
\hline \multicolumn{6}{|l|}{ Goodness of fit } \\
\hline$\rho^{2}$ & 0.075 & 0.079 & 0.078 & 0.080 & 0.081 \\
\hline Likelihood ratio test & $* * *$ & $* * *$ & $* * *$ & $* * *$ & $* * *$ \\
\hline
\end{tabular}

Notes: -- indicates the reference retail chain; ${ }^{*} p<.10 .{ }^{* *} p<.05 .{ }^{* * *} p<.01$.

\section{Conclusions}

In recent years the evolution of private labels has generated a remarkable increase in their market share in relation to national brands. Such growth has been linked to improvements in consumers' perceptions and attitudes toward those brands. Private label buyers no longer purchase these options just for their price; they also are motivated by favourable attitudes. We provide empirical evidence of this shift by analysing and comparing the effects of price sensitivity and quality perceptions of private labels on private label consumption. 
The development of private labels also has been characterized by increasing links with the retailer's positioning. Therefore, we offer updated empirical evidence of the retailer's price positioning as a moderator of the relative importance of price sensitivity and quality perceptions of private labels. Our results show that private label consumption can be explained by both price sensitivity and quality perceptions. The two determinants relate significantly to private label consumption. Moreover, we confirm a moderating effect of the retailer's price positioning, so that as the price level of a household's preferred retail chain increases, quality perceptions of private labels gain importance over price sensitivity as a determinant of private label purchases.

Retailers' apparent efforts to convert private labels into tools that reinforce positioning strategies thus appear well placed. They also have helped move the association of private labels away from an exclusive focus on price. The appeal of modern private labels encompasses both price and quality perceptions. In this sense, private labels may not only facilitate price competition but also help build the retailer's image and even differentiate the retailer from others. However, using private labels to differentiate the retail store demands both sufficient quality and the mitigation of other barriers, such as consumers' tendency to generalize private label experiences across retail chains (Szymanowski, Gijsbrechts 2012).

The results suggest the development of a private label portfolio with different positions along the price-quality continuum seems suitable for retailers whose positioning does not depend solely on price. On the one hand, private labels that are coherent with the retailer's quality positioning can attract the most demanding consumers and allows for direct competition with national brands. Because these private labels appear only in the specific retailer's stores, they also can enhance a retailer's differentiation and generate customer loyalty. On the other hand, a generic brand, focused more on price, should attract more price-sensitive customers and help the retailer compete better with more price-oriented retailers, such as discounters. Furthermore, generic offerings can enhance the credibility of private labels that focus on quality (Palmeira, Thomas 2011). However, generics do not contribute to retail differentiation and could be replaced by a product line with guaranteed low prices; for example, the retailer Alcampo is implementing its "economic products Alcampo" (Alcampo 2011) strategy.

Some limitations of this study suggest further research directions too. The measures we used could be improved substantially. We employed a general computation of quality perceptions of private labels, without measuring the specific perceptions for each private label or each product category. Specific analyses for different categories or private labels' positioning would probably provide more insightful results about the motivations for private label consumption. Although a retailer's price positioning is a complex, multidimensional concept, we measured it with a simple, one-dimensional scale. In addition, we did not include other private label purchase determinants, such as perceived risk or familiarity. Finally, we focus on the Spanish context. While Spain is a suitable scenario to analyse the private label phenomenon, due to the extraordinary development of private labels during the last years, further research should examine whether our findings are generalize to other countries. 


\section{Acknowledgements}

The authors thank TNS Spain (now KantarWorldpanel Spain) for providing the data used in this article. The authors also acknowledge the efforts of Cátedra Fundación Areces de Distribución Comercial, which aims to stimulate Spanish research; this article is based on Working Paper No. 07/2012, which the authors prepared for the Working Paper Collection of this nonprofit organization. This research was supported by Ministerio de Educación y Ciencia, Grant ECO2011-23381 (Spain).

\section{References}

Ailawadi, K. L; Pauwels, K.; Steenkamp, J.-B. E. M. 2008. Private label use and store loyalty, Journal of Marketing 72 (3): 19-30. http://dx.doi.org/10.1509/jmkg.72.6.19

Ailawadi, K. L.; Keller, K. L. 2004. Understanding retail branding: conceptual insights and research priorities, Journal of Retailing 80: 331-342. http://dx.doi.org/10.1016/j.jretai.2004.10.008

Ailawadi, K. L.; Neslin, S. A.; Gedenk, K. 2001. Pursuing the value-conscious consumer: store brands versus national brand promotions, Journal of Marketing 65: 71-89.

http://dx.doi.org/10.1509/jmkg.65.1.71.18132

Alba, J. W.; Broniarczyk, S. M.; Shimp, T. A.; Urbany, J. E. 1994. The influence of prior beliefs, frequency cues, and magnitude cues on consumers' perceptions of comparative price data, Journal of Consumer Research 21(2): 219-235. http://dx.doi.org/10.1086/209394

Alcampo. 2011. [Online], [cited 30 September 2011]. Available from Internet: http://www.alcampo.es/web/guest/primer-precio

Alimarket. 2007. Carrefour inaugura nueva era en marcas propias [online], [cited 30 September 2011]. Available from internet: http://alimarket.es/noticia/mr204010/CARREFOUR-INAUGURA-NUEVA-ERA-EN-MARCAS-PROPIAS

Alimarket. 2008. Informe anual de la distribución [online], [cited 30 May 2011]. Available from internet: http://alimarket.es

Apelbaum, E.; Gerstner, E.; Naik, P. A. 2003. The effects of expert quality evaluations versus brand name on price premiums, Journal of Product and Brand Management 12: 154-165.

http://dx.doi.org/10.1108/10610420310476915

Batra, R.; Sinha, I. 2000. Consumer-level factors moderating the success of private label brands, Journal of Retailing 76(Summer): 175-191. http://dx.doi.org/10.1016/S0022-4359(00)00027-0

Baltas, G. 1997. Determinants of store brand choice: a behavioral analysis, The Journal of Product and Brand Management 6(5): 315-325. http://dx.doi.org/10.1108/10610429710179480

Baltas, G. 2003. A combined segmentation and demand model for store brands, European Journal of Marketing 37(10): 149-1513. http://dx.doi.org/10.1108/03090560310487211

Baltas, G.; Argouslidis, P.C. 2007. Consumer characteristics and demand for store brands, International Journal of Retail \& Distribution Management 35(5): 328-341.

http://dx.doi.org/10.1108/09590550710743708

Bao, Y.; Bao, Y.; Sheng, S. 2010. Motivating purchase of private brands: effects of store image, product signatureness and quality variation, Journal of Business Research 64(2): 220-226.

http://dx.doi.org/10.1016/j.jbusres.2010.02.007

Burt, S. 2000. The strategic role of retail brands in British grocery retailing, European Journal of Marketing 34: 875-890. http://dx.doi.org/10.1108/03090560010331351

Burton, S.; Lichtenstein, D. R.; Netemeyer, R. G.; Garretson, J. A. 1998. A scale for measuring attitude toward private label products and an examination of its psychological and behavioral 
correlates, Journal of the Academy of Marketing Science 26(4): 293-306.

http://dx.doi.org/10.1177/0092070398264003

Carrefour. 2011. [Online], [cited 30 September 2011]. Available from Internet: http://www.carrefour.es/grupo-carrefour/las-marcas-carrefour/productos-carrefour/

Consumer Reports. 2009. It pays to buy store brands, October: 16-20.

Cunningham, I. C. M.; Hardy, A. P.; Imperia, G. 1982. Generic brands versus national brands and store brands, Journal of Advertising Research 22 (Oct/Nov): 223-232.

Davies, G.; Brito, E. 2004. Price and quality competition between brands and own brands: a value systems perspective, European Journal of Marketing 38: 30-55.

http://dx.doi.org/10.1108/03090560410511113

Dekimpe, M. G.; Gielens, K.; Raju, J.; Thomas, J. S. 2011. Strategic assortment decisions in information-intensive and turbulent environments, Journal of Retailing 87S(1): S17-S28.

http://dx.doi.org/10.1016/j.jretai.2011.04.006

De Wulf, K.; Odekerken-Schröder, G.; Goedertier, F.;Van Ossel, G. 2005. Consumer perceptions of store brands versus national brands, Journal of Consumer Marketing 22: 223-232.

http://dx.doi.org/10.1108/07363760510605335

Dhar, S. K.; Hoch, S. J. 1997. Why store brand penetration varies by retailer?, Marketing Science 16(3): 208-227. http://dx.doi.org/10.1287/mksc.16.3.208

Dick, A.; Jain, A.; Richardson, P. 1995. Correlates of store brand proneness: some empirical observations, The Journal of Product \& Brand Management 4: 15-22.

http://dx.doi.org/10.1108/10610429510097663

Dickson, P.; Sawyer, A. 1990. The price knowledge and search of supermarket shoppers, Journal of Marketing 54(July): 42-53. http://dx.doi.org/10.2307/1251815

Dunne, D.; Narasimhan, C. 1999. The new appeal of private labels, Harvard Business Review 77( May/Jun): 41-52.

East, R.; Hammond, K.; Harris, P.; Lomax, W. 2000. First-store loyalty and retention, Journal of Marketing Management 16(4): 307-325. http://dx.doi.org/10.1362/026725700784772907

Eleconomista. 2010. La marca propia de Eroski creció tres puntos en 2009, hasta lograr el $33 \%$ del total de las ventas [online], [cited 30 September 2011]. Available from Internet: http:// www.eleconomista.es/economia/noticias/2196796/06/10/Economia-Empresas-La-marca-propiade-Eroski-crecio-tres-puntos-en-2009-hasta-lograr-el-33-del-total-de-las-ventas.html

Erdem, T.; Zhao, Y.; Valenzuela, A. 2004. Performance of store brands: a cross-country analysis of consumer store-brand preferences, perceptions, and risk, Journal of Marketing Research 41(Feb): 86-100. http://dx.doi.org/10.1509/jmkr.41.1.86.25087

Fan, X.; Qian, Y.; Huang, P. 2012. Factors influencing consumer behaviour towards store brand: a meta-analysis, International, Journal of Market Research 54(3): 407-430.

http://dx.doi.org/10.2501/IJMR-54-3-407-430

Fornerino, M.; d'Hauteville, F. 2010. How good does it taste? Is it the product or the brand? A contribution to brand equity evaluation, Journal of Product and Brand Management 19: 34-43. http://dx.doi.org/10.1108/10610421011018374

Garretson, J. A.; Fisher, D.; Burton, S. 2002. Antecedents of private label attitude and national brand promotion attitude: similarities and differences, Journal of Retailing 78(2): 91-99. http://dx.doi.org/10.1016/S0022-4359(02)00071-4

Geyskens, I.; Gielens, K.; Gijsbrechts, E. 2010. Proliferating private-label portfolios: how introducing economy and premium private labels influences brand choice, Journal of Marketing Research 47(5): 791-807. http://dx.doi.org/10.1509/jmkr.47.5.791 
Hansen, K.; Singh, V. 2008. Are store-brand buyers store loyal? An empirical investigation, Management Science 54(10): 1828-1834. http://dx.doi.org/10.1287/mnsc.1080.0861

Hansen, K.; Singh, V.; Chintagunta, P. 2006. Understanding store-brand purchase behavior across categories, Marketing Science 25(1): 75-90. http://dx.doi.org/10.1287/mksc.1050.0151

Harris, B. F.; Strang, R. A. 1985. Marketing strategies in the age of generics, Journal of Marketing 49(Fall): 70-81. http://dx.doi.org/10.2307/1251433

Hoch, S. J. 1996. How should national brands think about private labels?, Sloan Management Review Winter: 89-102.

Hoch, S. J.; Banerji, S. 1993. When do private labels succeed?, Sloan Management Review 34(4): 57-67.

IGD Research. 2007. European discount retailing [online], [cited 30 September 2011]. Available from Internet: http://www.igd.com/

KantarWorldpanel. 2010. La distribución en tiempos difíciles. Reacciones y resultados.

KantarWorldpanel. 2011. Balance 2010 del sector de gran consumo [online], [cited 30 September 2011]. Available from Internet: http://www.kantarworldpanel.com/kwp_ftp/Spain/NdP/20110209_balance2010/20110209_balance2010_presentacion.pdf

Kumar, N.; Radhakrishnan, S.; Rao, R. C. 2010. Private label vendor selection in a supply chain: quality and clientele effects, Journal of Retailing 86(2): 148-158.

http://dx.doi.org/10.1016/j.jretai.2010.02.007

Kumar, N.; Steenkamp, J.-B. E. M. 2007. Private label strategy: how to meet the store brand challenge. Boston, MA: Harvard Business School Press.

Lamey, L.; Deleersnyder, B.; Dekimpe, M. G.; Steenkamp, J.-B. E. M. 2007. How business cycles contribute to private-label success: evidence from the United States and Europe, Journal of Marketing 71(January): 1-15. http://dx.doi.org/10.1509/jmkg.71.1.1

Lamey, L.; Deleersnyder, B.; Dekimpe, M. G.; Steenkamp, J.-B. E. M.; Dekimpe, M. G. 2012. The effect of business-cycle fluctuations on private-label share: what has marketing conduct got to do with it?, Journal of Marketing 76(1): 1-19. http://dx.doi.org/10.1509/jm.09.0320

Luijten, T.; Reijnders, W. 2009. The development of store brands an store as a brand in supermarkets in the Netherlands, International Review of Retail, Distribution \& Consumer Research 19(1): 45-58. http://dx.doi.org/10.1080/09593960902781268

Manzur, E.; Olavarrieta, S.; Hidalgo, P.; Farías, P.; Uribe, R. 2011. Store brand and national brand promotion attitudes antecedents, Journal of Business Research 64: 286-291.

http://dx.doi.org/10.1016/j.jbusres.2009.11.014

Martos-Partal, M.; González-Benito, O. 2009. Qué busca el comprador de marcas de distribuidor? Caracterización del comprador de marca de distribuidor por beneficios buscados, Universia Business Review 24: 76-95.

Mendéz, J. L.; Oubiña, J.; Rubio, N. 2008. Expert quality evaluation and price of store vs. manufacturer brands: an analysis of the Spanish mass market, Journal of Retailing and Consumer Services 15: 144-155. http://dx.doi.org/10.1016/j.jretconser.2007.11.003

McDowell, A.; Cox, N. J. 2004. Logit transformation [online], [cited 3 April 2011]. Available from Internet: http://www.stata.com/support/faqs/stat/logit.html

Nielsen, A. 2011. The rise of the value-conscious shopper. A Nielsen global private label report, March [Online], [cited 30 September 2011]. Available from Internet: http://hk.nielsen.com/documents/PrivateLabelGlobalReport.pdf

OCU. 2008. OcuCompra Maestra 331(November): 31-40.

Olson, E. L. 2012. Supplier inferences to enhance private label perceptions, Journal of Business Research 65(1): 100-105. http://dx.doi.org/10.1016/j.jbusres.2011.02.004 
Palmeira, M. M.; Thomas, D. 2011. Two-tier store brands: the beneficial impact of a value brand on perceptions of a premium brand, Journal of Retailing 87(4): 540-548.

http://dx.doi.org/10.1016/j.jretai.2011.09.004

Pan, Y.; Zinkhan, G. M. 2006. Determinants of retailing patronage: a meta-analytical perspective, Journal of Retailing 82(3): 229-243. http://dx.doi.org/10.1016/j.jretai.2005.11.008

PLMA (Private Label Manufacturers Association). 2010. [Online], [cited 25 May 2010]. Available from Internet: http://www.plmainternational.com/en/private_label_en3.htm

PLMA (Private Label Manufacturers Association). 2011. [Online], [cited 24 January 2011]. Available from Internet: http://plma.com/storeBrands/sbt10.html

Quelch, J. A.; Harding, D. 1996. Brands versus private labels: fighting to win, Harvard Business Review 74(1): 99-109.

Rhee, H.; Bell, D. R. 2002. The inter-store mobility of supermarket shoppers, Journal of Retailing 78: 225-237. http://dx.doi.org/10.1016/S0022-4359(02)00099-4

Richardson, P. S.; Dick, A. S.; Jain, A. K. 1996. Household store brand proneness: a framework, Journal of Retailing 72(Summer): 159-185. http://dx.doi.org/10.1016/S0022-4359(96)90012-3

Richardson, P. S.; Dick, A. S.; Jain, A. K. 1994. Extrinsic and intrinsic cue effects on perceptions of store brand quality, Journal of Marketing 58(Oct): 28-36. http://dx.doi.org/10.2307/1251914

Rubio, N.; Yagüe, M. J. 2009. Alternative panel models to evaluate the store brand market share: evidence from the Spanish market, European Journal of Marketing 43(1/2): 110-138.

http://dx.doi.org/10.1108/03090560910923265

Semeijn, J.; van Riel, A. C. R.; Ambrosini, A. B. 2004. Consumer evaluations of store brands: effects of store image and product attributes, Journal of Retailing and Consumer Services 11(4): 247-58. http://dx.doi.org/10.1016/S0969-6989(03)00051-1

Sethuraman, R. 2006. Private-label marketing strategies in packaged goods: management beliefs and research insights, Marketing Science Institute Working Paper, 27-44.

Sethuraman, R.; Cole, C. 1999. Factors influencing the price premiums that consumers pay for national brands over store brands, Journal of Product and Brand Management 8: 340-351.

http://dx.doi.org/10.1108/10610429910284319

Sinha, I.; Batra, R. 1999. The effect of consumer price consciousness on private label purchase, International Journal of Research in Marketing 16: 237-251.

http://dx.doi.org/10.1016/S0167-8116(99)00013-0

Soberman, D. A.; Parker, P. M. 2006. The economics of quality-equivalent store brands, International Journal of Research in Marketing 23(June): 125-139.

http://dx.doi.org/10.1016/j.ijresmar.2005.09.008

Steenkamp, J.-B.; van Heerde, H. J.; Geykens, I. 2010. What makes consumers willing to pay a price premium for national brands over private labels?, Journal of Marketing Research 47(6): 1011-1024. http://dx.doi.org/10.1509/jmkr.47.6.1011

Szymanowski, M.; Gijsbrechts, E. 2012. Consumption-based cross-brand learning: are private labels really private?, Journal of Marketing Research 49(2): 231-246.

http://dx.doi.org/10.1509/jmr.07.0416

Yelkur, R. 2000. Consumer perceptions of generic products: a Mexican study, Journal of Product and Brand Management 9: 446-456. http://dx.doi.org/10.1108/10610420010351385

Zielke, S. 2010. How price image dimensions influence shopping intentions for different store formats, European Journal of Marketing 44(6): 748-770. 
Óscar GONZÁLEZ-BENITO has a degree in Mathematics from the University of Salamanca, a MSc degree in Marketing from UMIST (UK) and a PhD in Economics and Management Sciences from the University of Salamanca. He is Professor of Marketing at the University of Salamanca. In addition to publications in some of the most well-recognized Spanish marketing and management journals, he has published in international journals such as Journal of Retailing, Psychology \& Marketing, European Journal of Marketing, Journal of Business Research, Industrial Marketing Management, International Journal of Market Research, British Journal of Management, Marketing Letters, OMEGA and Small Business Economics.

Mercedes MARTOS-PARTAL (PhD, University Carlos III of Madrid) is Assistant Professor (Tenure Track) of Marketing at the University of Salamanca. Her current research interests focus on the private label phenomenon, relationship marketing issues and analyses of the consumer packaged goods industry. She has published in international journals such as Journal of Retailing, Psychology \& Marketing, Marketing Letters, International Journal of Market Research, Journal of Marketing Management, Journal of Retailing and Consumer Service, Journal of the Academy of Business Education, International Review on Public and Non Profit Marketing, African Journal of Business Management and International Review of Retail, Distribution and Consumer Research, as well as in prestigious Spanish journals, including Revista Española de Investigación de Marketing-ESIC and Universia Business Review. 